\title{
Tuberculosis in Elephants: A Zoonotic Disease at the Human-Elephant Interface
}

\author{
Sarad PAUDEL and Toshio TSUBOTA* \\ Laboratory of Wildlife Biology and Medicine, Graduate School of Veterinary Medicine, Hokkaido University, \\ Kita 18, Nishi 9, Sapporo 060-0818, Japan
}

[Received 15 February 2016; accepted 14 March 2016]

\begin{abstract}
Tuberculosis (TB) in elephants is a re-emerging disease predominantly caused by Mycobacterium tuberculosis, a human type of TB. Elephant to human TB transmission has been reported from several zoological facilities which have public health implications. Culture of respiratory samples obtained using a trunk wash procedure is regarded as the gold standard for TB diagnosis in elephants; however, this technique has many limitations. Serological methods have been developed and are widely used for TB testing in elephants in zoos around the world and elephant facilities in Asian elephant range countries. Regular TB screening of elephants and their handlers should be performed; infected elephants and handlers should be segregated and treated with anti-TB drugs according to established treatment regimens. Screening, segregation, and treatment will aid in the prevention of TB transmission between species and will contribute to the conservation of endangered wild elephants by mitigating TB spread at the captive-wild interface.
\end{abstract}

Key words: Asian elephants, Elephas maximus, Mycobacterium tuberculosis, Tuberculosis

— Jpn.J. Zoo. Wildl. Med. 21(3) : 65-69, 2016

\section{INTRODUCTION}

TB in elephants is a re-emerging disease primarily caused by M. tuberculosis, a human form of TB; however, infection by M. bovis has also been infrequently reported [1-3]. TB is an ancient disease of humans and elephants. The first published case of TB in an elephant in modern times was reported at the London Zoo in 1875 [4]. Scientific study of elephant TB did not begin until 1996 after two circus elephants died of this disease in the USA [5]. The United States Department of Agriculture (USDA) developed the first elephant TB guidelines in 1997. These were revised in 2000, 2003, 2008, and 2010 as new information became available. These guidelines provide recommendations for the testing, treatment, and surveillance of TB in elephants [6]. Between 1994 and 2013, 57 elephants in the USA were culture-positive for TB. M. tuberculosis was isolated from 56 elephants and M. bovis was isolated from one elephant [7]. TB screening has been initiated in zoos and

\footnotetext{
* Corresponding author :

Toshio TSUBOTA (E-mail: tsubota@vetmed.hokudai.ac.jp)
}

elephant collections in many countries in the world. TB was confirmed in 5 elephants post-mortem by culture in a Swedish zoo [8, 9]. TB was diagnosed in an Asian elephant imported from Thailand in a facility of Australia and later was spread to chimpanzees housed nearby [10].

Screening of TB in elephants has taken place in Nepal, India, Thailand, Sri Lanka, Malaysia and Laos. All of these countries have a high prevalence of TB in the human population. Intermingling of humans and elephants during various religious and tourist activities such as elephant rides provides ample opportunity for transmission of this disease from humans to elephants or elephants to humans. The true risk of transmission at these events is unknown. TB was first reported in Nepalese captive elephants in Chitwan National Park in 2002 [11]. Since then, more than 10 elephants have died of this disease in Nepal. Recently, M. tuberculosis isolated from 3 captive elephants of Nepal was identified as belonging to the Indo-Oceanic lineage which is also found among human TB patients in Nepal [12]. This shows that there is transmission of TB between humans and elephants. The Nepal Elephant Tuberculosis Control and Management Action Plan (2011- 
2015) has been endorsed by the Government of Nepal and provides guidelines for the diagnosis, treatment and monitoring of TB in elephants of Nepal [13].

A study in India has shown that $15 \%$ of over 300 captive elephants tested were sero-reactive using a commercial test, the Elephant TB Stat-Pak Assay (ChemBio Diagnostics, Inc., Medford, NY, USA) and the highest seroreactivity was among the temple elephants having the greater contact with the humans [14]. M. tuberculosis was isolated from 2 wild Asian elephants in India [15] and from a wild elephant in Sri Lanka [16]. In Thailand, 4 elephants were confirmed positive for TB by culture [17]. Similarly, serological testing using the Elephant TB Stat-Pak Assay ${ }^{\circledR}$ (Chembio Diagnostics, Inc., Medford NY, USA) in Malaysian elephants showed that 20.4\% of the elephants tested were sero-positive [18]. A study in Lao PDR revealed that $36 \%$ of the tested elephants were seroreactive on the Stat-Pak assay [19].

\section{DIAGNOSTIC CHALLENGES OF ELEPHANT TB}

The majority of elephants infected with TB do not show any clinical signs; however, some may have chronic weight loss, anorexia, exercise intolerance, and weakness. In some cases, elephants may manifest symptoms only in the advanced stage of disease, or TB may not be diagnosed until necropsy [1, 2]. The post-mortem lesions in elephants that died of TB include granulomatous nodules in the lungs and bronchial lymph nodes and sometimes with caseous foci [2]. Histologically, the multiple, coalescing, nodular accumulation of foamy to epitheliod macrophages as well as few multi-nucleated giant cells distorting the alveoli were found in the tubercle lesions in the lungs of two third of elephants that died of TB infected elephants [20].

According to USDA guidelines, culture of trunk wash samples is regarded as the gold-standard for the diagnosis of TB in elephants [6], however, this technique has many limitations. The elephants must be well-trained to collect a proper sample using this technique. Elephants shed M. tuberculosis intermittently, so trunk wash samples should be collected on at least three separate days and multiple samples collected over a course of weeks to months may be needed before a positive culture is obtained. M. tuberculosis is slow-growing and final culture results are not available for six to eight weeks. We collected a series of trunk wash cultures from TB- suspected elephants in Nepal; however, we were not successful in isolating the organism. Unfortunately, chest X-ray is impossible in elephants and the intradermal tuberculin test is not reliable $[5,8]$. TB can also be diagnosed using other methods including nucleic acid amplification techniques (NAAT), ELISA, interferon-gamma assay and immunoblot assay, however, these techniques have not yet been validated in elephants [2].

Recently, two serological tests, the ElephantTB STAT-PAK ${ }^{\circledR}$ and the DPP VetTB ${ }^{\circledR}$ Assay (ChemBio Diagnostic Systems, Inc., Medford, NY, USA) were developed and licensed as screening tests for TB in elephants. These tests have been commonly used for testing elephants around the world and have proved to be useful for the early diagnosis of TB in elephants [21, 22]. The Stat-Pak has been replaced by the DPP and is no longer available. These tests detect antibodies against the dominant TB antigens in elephants, often months to years before $M$. tuberculosis can be isolated in culture [23]. An interferongamma release assay (IGRA) has also been developed that may work as a potential diagnostic tool for TB diagnosis in elephants, however, this assay still needs to be validated in a large population of TB infected and non-infected elephants [24].

\section{TB TRANSMISSION AT ELEPHANT-HUMAN INTERFACE}

TB is highly prevalent among humans in elephant range countries in south and south-east Asia. The prolonged contact between captive elephants and their handlers suggests that handlers may be at the greatest risk of contracting TB from elephants or transmitting TB to elephants, however, further epidemiological studies are needed. TB transmission between elephants and humans was reported in USA. In one facility in the USA, 11 of 22 elephant handlers were reactive on the intradermal tuberculin test. Among them, one elephant handler had suspicious lesions on chest radiographs and a sputum culture was positive for M. tuberculosis. The IS6100 restriction fragment length polymorphism (RFLP) pattern from this handler matched that of the culture-positive elephants at the facility which showed that the inter-species transmission of TB can occur between elephants and humans [25]. In another case, $M$. tuberculosis was isolated from 2 elephants, 3 Rocky Mountain goats and a black rhinoceros at Los Angeles Zoo in the USA. Among 307 individuals screened by skin testing, 15 personnel, mostly involved in elephant training, necropsy, and grounds keeping of elephants, demonstrated intradermal tuberculin test conversion [26]. Similarly, in an elephant refugee in south-central Tennessee, USA, which had 
an elephant with active TB, 9 employees had PPD conversion; however, none of the employee had active TB [27]. A study from the elephant facilities in Malaysia showed that the seroprevalence of $\mathrm{TB}$ in the elephants and their handlers was $20.4 \%$ and $24.8 \%$, respectively, suggesting two-way transmission between animals and humans within confined workplaces, however, none of the samples from elephants and handlers were culture positive [18]. A recent study from two protected areas of Nepal showed that 3 captive elephants were infected with $M$. tuberculosis belonging to Indo-oceanic lineage that is also prevalent in the TB infected human population in Nepal. The elephants might have become infected with TB from the closely working with people, most probably their handlers [12]. Thus, these studies show that there are always higher possibilities of transmission of TB between elephants and humans.

\section{CONCLUSION}

$\mathrm{TB}$ is re-emerging as a zoonotic disease in elephant collection facilities worldwide as well as in elephant range countries. This directly poses a greater risk of transmission of this disease from infected elephants to other endangered mammalian species as well as the people working with them. As the elephants are mostly infected with $M$. tuberculosis, this shows that elephants are acquiring TB from infected humans. For the effective prevention of TB infection in elephants, TB screening of persons working directly with elephants should be performed. TB-infected handlers should be treated for TB following the Directly Observed Treatment Short course (DOTS) regimen and separated from their working elephants until they are no longer shedding. Similarly, captive elephants should be regularly tested for TB using the serological test and trunk wash culture. TB-infected elephants should be placed in segregation and treated with anti-tuberculosis drugs according to developed treatment protocols. Similarly, TB-suspected and especially TB-confirmed elephants should be rested and refrained from participating in activities like religious ceremonies or elephant races where TB could be transmitted to other susceptible hosts. The regular screening of elephants and their handlers will help in the prevention, control, and transmission of this disease in elephants and other susceptible hosts thus supporting conservation efforts for this endangered species.

\section{ACKNOWLEDGEMENT}

We acknowledge Dr. Susan Mikota, Director of Veterinary Program and Research, Elephant Care International, USA for her great support in our elephant TB research as well as valuable input on this manuscript. We are grateful to the members of Laboratory of Wildlife Biology and Medicine, Graduate School of Veterinary Medicine, Hokkaido University, Japan for their great co-operation and support in our elephant TB study in Nepal. We thank Prof. Yasuhiko Suzuki and Dr. Chie Nakajima from Hokkaido University Research Center for Zoonosis Control for their kind support and guidance in elephant TB research. We also want to acknowledge the Department of National Parks and Wildlife Conservation (DNPWC), Government of Nepal and the National Trust for Nature Conservation (NTNC) for providing great support for our elephant TB research in Nepal. We want to thank the Leading Program at Graduate School of Veterinary Medicine, Hokkaido University, Japan for funding to conduct our field study in Nepal.

\section{REFERENCES}

1. Mikota SK., Larsen RS, Montali RJ. 2000. Tuberculosis in elephants in North America. Zoo Biol 19: 393-403.

2. Mikota SK. 2008. Tuberculosis in elephants. In Zoo and Wild Animal Medicine, Current Therapy, 6th ed (Fowler ME, Miller RE ed), pp. 355-364. Saunders/Elsevier, St. Louis.

3. Payeur JB, Jarnagin JL, Marquardt JG, Whipple DL. 2002. Mycobacterial isolations in captive elephants in the United States. Ann N Y Acad Sci 969: 256-258.

4. Garrod AH. 1875. Report on the Indian elephant which died in the Society's gardens on July 7th, 1875. Proc Zoo Soc London, pp. 542-543.

5. Mikota SK, Peddie L, Peddie J, Isaza R, Dunker F, West G, Lindsay W, Larsen RS, Salman MD, Chatterjee D, Payeur J, Whipple D, Thoen C, Davis DS, Sedgwick C, Montali RJ, Ziccardi M, Maslow J. 2001. Epidemiology and diagnosis of Mycobacterium tuberculosis in captive Asian elephants (Elephas maximus). J Zoo Wildl Med 32:1-16.

6. Guidelines for the Control of Tuberculosis in Elephants. 2010. Committee on Tuberculosis. Animal Health Association, St Joseph, MO, US.

7. Maslow JN, Mikota SK. 2015. Tuberculosis in Elephants - A reemergent disease: Diagnostic dilemmas, the natural history 
of infection, and new immunological tools. Vet Pathol 52(3): 437-440.

8. Lewerin SS, Olsson SL, Eld K, Röken B, Ghebremichael S, Koivula T, Källenius G, Bölske G. 2005. Outbreak of Mycobacterium tuberculosis infection among captive Asian elephants in a Swedish zoo. Vet Rec 156: 171-175.

9. Moller T, Roken B, Petersson L, Vitaud C, Lyashchenko K. 2005. Preliminary results of a new serological test for detection of TB-infection (Mycobacterium tuberculosis) in elephants (Elephas maximus and Loxodonta africanum) Swedish case studies. Verh ber Erkg Zootiere 42: 173-181.

10. Stephens N, Vogelnest L, Lowbridge C, Christensen A, Marks GB, Sintchenko V, McAnulty J. 2013. Transmission of Mycobacterium tuberculosis from an Asian elephant (Elephas maximus) to a chimpanzee (Pan troglodytes) and humans in an Australian zoo. Epidemiol Infect 141: 1488-1497.

11. Gairhe, K. 2002. A case study of tuberculosis in captive elephants in Nepal. Report Submitted to Department of National Parks and Wildlife Conservation, Kathmandu, Nepal.

12. Paudel S, Mikota SK, Nakajima C, Gairhe KP, Maharjan B, Thapa J, Poudel A, Shimozuru M, Suzuki Y, Tsubota T. 2014. Molecular characterization of Mycobacterium tuberculosis isolates from elephants of Nepal. Tuberculosis (Edinb) 94: 287-292.

13. Nepal elephant tuberculosis control and management Action Plan (2011-2015). 2011. Government of Nepal, Ministry of Forests and Soil Conservation, Department of National Parks and Wildlife Conservation, Kathmandu, Nepal.

14. Abraham D, Cheeran JV, Sukumar R, Mikota SK, Rao S, Ganguly S, Varma S. 2008. Health assessment of captive Asian elephants in India with special reference to tuberculosis. Report to Project Elephant, Ministry of Environment and Forests, Government of India, New Delhi.

15. Zachariah A. 2012. Emerging diseases in the single largest Asian elephant (Elephas maximus indicus) population, Nilgiri Biosphere Reserve, South India. Report to United States Fish and Wildlife Service Asian Elephant Conservation Fund.

16. Perera BVP, Salgadu MA, Gunawardena GSPS, Smith NH, Jinadasa HRN. 2014. First confirmed case of fatal tuberculosis in a Wild Sri Lankan elephant. Gajah 41: 28-31.

17. Angkawanish T, Wajjwalku W, Sirimalaisuwan A, Mahasawangkul S, Kaewsakhorn T, Boonsri K, Rutten VP. 2010. Mycobacterium tuberculosis infection of domesticated Asian elephants, Thailand. Emerg Infect Dis 16: 1949-1951.
18. Ong BL, Ngeow YF, Razak MF, Yakubu Y, Zakaria Z, Mutalib AR, Hassan L, Ng HF, Verasahib K. 2013. Tuberculosis in captive Asian elephants (Elephas maximus) in Peninsular Malaysia. Epidemiol Infect 141: 1481-1487.

19. Lassausaie J, Bret A, Bouapao X, Chanthavong V, Castonguay-Vanier J, Quet F, Mikota SK, Théorêt C, Buisson Y, Bouchard B. 2015. Tuberculosis in Laos, who is at risk: the mahouts or their elephants? Epidemiol Infect 143: 922-931.

20. Landolfi JA, Terio KA, Miller M, Junecko BF, Reinhart T. 2015. Pulmonary tuberculosis in Asian elephants (Elephas maximus): histologic lesions with correlation to local immune responses. Vet Pathol 52: 535-542.

21. Greenwald R, Lyashchenko O, Esfandiari J, Miller M, Mikota S, Olsen JH, Ball R, Dumonceaux G, Schmitt D, Moller T, Payeur JB, Harris B, Sofranko D, Waters WR, Lyashchenko KP. 2009. Highly accurate antibody assays for early and rapid detection of tuberculosis in African and Asian elephants. Clin Vaccine Immunol 16: 605-612.

22. Lyashchenko KP, Greenwald R, Esfandiari J, Olsen JH, Ball R, Dumonceaux G, Dunker F, Buckley C, Richard M, Murray S, Payeur JB, Andersen P, Pollock JM, Mikota S, Miller M, Sofranko D, Waters WR. 2006. Tuberculosis in elephants: antibody responses to defined antigens of Mycobacterium tuberculosis, potential for early diagnosis, and monitoring of treatment. Clin Vaccine Immunol 13: 722-32.

23. Lyashchenko KP, Greenwald R, Esfandiari J, Mikota S, Miller M, Moller T, Vogelnest L, Gairhe KP, Robbe-Austerman S, Gai J, Waters WR. 2012. Field application of serodiagnostics to identify elephants with tuberculosis prior to case confirmation by culture. Clin Vaccine Immunol 19:12691275.

24. Angkawanish T, Morar D, van Kooten P, Bontekoning I, Schreuder J, Maas M, Wajjwalku W, Sirimalaisuwan A, Michel A, Tijhaar E, Rutten V. 2013. The elephant interferon gamma assay: a contribution to diagnosis of tuberculosis in elephants. Transbound Emerg Dis 60 (Suppl 1): 53-59.

25. Michalak K, Austin C, Diesel S, Bacon MJ, Zimmerman P, Maslow JN. 1998. Mycobacterium tuberculosis infection as a zoonotic disease: transmission between humans and elephants. Emerg Infect Dis 4: 283-287.

26. Oh JY, Kim KS, Jeong YW, Cho JW, Park JC, Lee JC. 2002. Human exposure following Mycobacterium tuberculosis infection of multiple animal species in a metropolitan zoo. Emerg Infect Dis 8: 1290-1293. 
TF. 2011. Elephant-to-human transmission of tuberculosis,

\title{
ゾウにおける結核：ヒトとゾウの間を伝播する人獣共通感染症
}

\author{
Sarad PAUDEL，坪田敏男* \\ 北海道大学大学院獣医学研究科野生動物学教室 $=060-0818$ 北海道札幌市北区北 18 条西 9 丁目
}

[2016 年 2 月 15 日受領, 2016 年 3 月 14 日採択]

\section{要 約}

ゾウにおける結核は, ヒト型結核の病原体である Mycobacterium tuberculosis によって主に引き起こされる再興感染症の 1 つ である。ゾウからヒトへの伝播が, いくつかの動物園で報告されており, 公衆衛生上大きな問題となっている。ゾウの鼻腔洗浄に よって得られる呼吸器系サンプルの培養が, ゾウ結核診断の最も信頼できる手法である。しかしながら, この手法の適用はあまり 現実的でない。世界の動物園やゾウ飼育施設では, ゾウの結核診断法として抗体検査が開発され，広く使われている。ゾウと象使 いでの定期的な結核スクリーニング検査が実施されるべきである。結核陽性の象使いはすぐに隔離され, 抗結核薬が処方されるべ きである。スクリーニング検査, 隔離および治療はゾウとヒトと間での結核伝播を防ぐのに有効であり, 飼育ゾウー野生ゾウ間の 結核感染の広がりを抑えることが絶滅危惧種である野生ゾウの保全に貢献することにつながる。

キーワード : アジアゾウ, Elephas maximus, 結核, Mycobacterium tuberculosis

一日本野生動物医学会誌 21(3)：65-69, 2016

\section{*責任著者：}

坪田敏男 (E-mail: tsubota@vetmed.hokudai.ac.jp) 